\title{
PENDAMPINGAN PENGGUNAAN APLIKASI RT ONLINE
}

\author{
ADMINISTRATION OF USE OF APPLICATION RT ONLINE \\ ${ }^{1)}$ Dwi Krisbiantoro, ${ }^{2)}$ Abdul Azis, ${ }^{3)}$ Banu Dwi Putranto \\ ${ }^{1,2,3)}$ Program Studi Sistem Informasi \\ Fakultas Ilmu Komputer Universitas AMIKOM Purwokerto \\ Jl.Letjen. Pol.Soemarto Watumas Purwanegara Purwokerto Utara \\ Email : dwikris@amikompurwokerto.ac.id
}

\begin{abstract}
ABSTRAK
Tujuan kegiatan ini yaitu untuk memberikan pengetahuan pelatihan dan pendampingan penggunaan aplikasi RT online pada masyarakat Teluk khususnya RT 02 RW 03. Metode pelaksanan ini menggunakan metode ceramah, demonstrasi dan juga praktik aplikasi RT online yang diikuti oleh perwakilan warga sebanyak 15 orang Hasil yang diperoleh adalah warga telah mampu menggunakan aplikasi RT online guna memudahkan urusan administrasi RT dan melihat informasi yang ada di RT dalam menggunakan aplikasi RT online sehingga lebih efektif dan efisien dalam mendapatkan informasi dan urusan administrasi RT. Hasil dari pendampingan yang telah dilakukan dapat di sebarluaskan ke warga lain sehingga semua warga dapat memanfaatkan adanya teknologi baru di lingkungan RT 02 RW 03.
\end{abstract}

Kata kunci: Aplikasi; RT; Online; Informasi

\begin{abstract}
The purpose of this activity is to provide knowledge of training and assistance in the use of online RT applications in the Gulf community, especially RT 02 RW 03. The method of implementation uses lectures, demonstrations, and also the practice of online RT applications that are participated by representatives of as many as 15 people. The results obtained are residents have been able to use the $R T$ online application to facilitate RT administrative matters and see information in the RT in using the $R T$ online application so that it is more effective and efficient in obtaining information and $R T$ administrative matters. The results of the assistance that have been carried out can be disseminated to other residents so that all residents can take advantage of new technologies in RT 02 RW 03.
\end{abstract}

Keywords: Application; RT; Online; Information

\section{PENDAHULUAN}

Seiring dengan pertumbuhan jumlah penduduk akan berdampak pula pada kehidupan bermasyarakat dan bersosial baik di daerah perkotaan maupun dipedasaan. Kehidupan bermasyarakat pada tingkatan paling bawah diatur oleh Peraturan Pemerintah melalui Pemendagri nomor 5 tahun 2007 yang mengatur tentang Pembentukan Rukun Warga dan Rukun Tetangga.
Meskipun ditujukan sebagai lembaga kemasyarakatan, Rukun Tetangga dan Rukun Warga pada hakekatnya dilahirkan untuk membantu berbagai pelaksanaan kegiatan. Peran Rukun Tetangga dalam kehidupan bermasyarakat mempunyai peran yang cukup penting karena sebagai kontrol warga dalam kehidupan bersosial dan bermasyarakat dan membantu pemerintahan di tingkat yang lebih tinggi desa atau kelurahan. 
Kelurahan Teluk khususnya di RT 02 memiliki $92 \mathrm{KK}$ yang tersebar diwilayah RT 02 yang rata-rata warganya sebagian adalah pendatang dan dari berbagai macam jenis Profesi dan kesibukan warganya masing-masing hal ini tentu perlu kontrol dari ketua RT agar tertib secara kependudukan dan dapat memberikan laporan kepada kelurahan secara cepat, namun pendataan warga selama ini masih dilakukan secara konvensional dicatat dibuku dan tentunya kesulitan dalam pencarian data secara cepat.

Sebagai upaya dari pihak RT untuk mendata warganya telah dilakukan dengan memanfaatkan teknologi yaitu aplikasi RT online tetapi masih mengalami kendala, diantaranya warga secara umum belum paham cara penggunaannya meskipun ditiap pertemuan RT sudah dilakukan sosialisasi tetapi penggunaan dari aplikasi RT online belum maksimal sepenuhnya dilakukan oleh warga, mereka masih tetap datang ke pengurus RT hanya untuk meminta surat padahal dengan menggunakan aplikasi RT online warga dapat melakukan pengajuan surat sendiri dan tentu hal ini lebih efisien, karena belum tentu pengurus RT berada di rumah sehingga warga kadang pulang lagi hal ini tentu menjadi kurang maksimal dalam pelayanan terhadap warga.

Internet merupakan salah satu dari kecanggihan teknologi informasi dan komunikasi. Dengan menggunakan internet memungkinkan individu memperoleh informasi apapun yang ada dan bertukar informasi tanpa terhambat oleh batas ruang dan waktu (Bariyyah \& Permatasari, 2017).

Dengan memanfaatkan teknologi internet masyarakat dapat dengan mudah mendapatkan informasi seperti melihat informasi warga yang berada di RT 02 ada berapa jumlahnya, status pekerjaan warga dan seterusnya hingga pengurusan surat pengantar dapat dilakukan tanpa harus datang meminta ke pengurus RT dengan mengisi blangko yang diisi oleh pengurus RT, warga dapat mencetak sendiri suratanya dari rumah barulah datang ke pengurus RT untuk meminta pengesahan dan dari sisi pengurus RT dapat dengan mudah mendata warganya dan menyajikan informasi terkait dengan RT secara cepat jika ada pihak-pihak yang meminta data warganya berdasarkan jenis kelamin, umur ataupun status warganya.

Melihat perkembangan teknologi saat ini sudah sangat cepat dan tingkat mobilisasi warga yang sibuk dan bahkan dalam kawasan satu RT sesama warga tidak saling kenal hal ini tentu dapat menjadi kurang baik dalam hidup bersosialisasi untuk itu perlu adanya sebuah inovasi agar warga dapat saling kenal satu dengan yang lain walaupun jarang bertemu karena kesibukan warganya melalui aplikasi RT online yang dapat diakses melalui internet ataupun berbasis android.

Teknologi andorid dan internet telah berkembang cukup pesat dan memiliki berbagai versi, berdasarkan survey yang dilakukan oleh APJII (Asosiasi Penyelenggara Jasa Internet Indonesia pengguna internet meningkat dari tahun 2016-2017 sebesar 132,7 Juta Jiwa hal ini tentu membuktikan bahwa masyarakat Indonesia telah mengerti dan sering berinteraksi dengan internet baik dari perkotaan maupun di pedesaan tetapi belum memanfaatkan internet secara maksimal.

Tujuan dilaksanakannya kegiatan ini untuk meningkatkan pengetahuan dan keterampilan penggunaan aplikasi Rukun Tetangga secara online pada masyarakat Teluk khususnya RT 02 RW 03 Kecamatan Purwokerto Selatan Kab. Banyumas.

\section{METODE}

Metode yang digunakan berupa pendampingan atau pelatihan penggunaan aplikasi RT online dengan cara ceramah dan praktik langsung yang dilakukan bersama dengan warga sebanyak 15 orang dengan memilih warga yang berusia 
sekitar 17-40 tahun, karena rata-rata pengguna internet adalah usia muda (Survey APJII. 2019.) Alasan memilih warga dengan rentan usia muda adalah rata-rata mereka telah terbiasa berinteraksi dengan internet dan platform smartphone android sehingga didalam pendampingan akan lebih mudah dan nantinya merekaakan terbiasa dengan penggunaan aplikasi RT online untuk kedepannya, karena usia tersebutakan sering berhubungan dengan masalah administrasi di tingkat RT misal meminta surat pengantar untuk mengurus SKCK dan seterusnya.

Untuk melihat tingkat keberhasilan dalam kegiatan pendampingan penggunaan aplikasi RT online dianalisis dengan teknik paired sample T-Test (Sugiono, 2012) yaitu untuk melihat ada tidaknya perbedaan gain score antara pretest dan post test yang berjumlah 15 orang.

Kegiatan dimulai dengan memberikan modul dan tutorial cara penggunaan aplikasi RT online beserta fungsinya dan bagaimana cara mengaksesnya setelah mereka membaca kemudian dilakukan pretest untuk mengetahui tingkat pemahaman mereka terhadap fungsi dan cara penggunaan aplikasi RT online.

Setelah tahapan pretest dilakukan kemudian dilakukan pelatihan pendampingan penggunaan aplikasi RT online secara demonstrasi langsung dan dijelaskan tahap tahapan dan fungsi fitur fitur yang ada secara detail serta diberikan contoh pengurusan surat pengantar secara online dari warga ke pengurus RT.

Dalam pengabdian ini dirancang konsep berdasarkan web application yang merupakan sebuah aplikasi yang diakses menggunakan web browser dan dikembangkan dengan browser- supported languages seperti HTML dan Java script. Untuk menjalankannya,web application bergantung kepada web browser yang memiliki banyak aplikasi yang sering digunakan seperti aplikasi penjualan online, lelang online dan webmail (AlFedaghi, 2011).

Dengan penerapan aplikasi RT Online ini diharapakan dapat memberikan efektifitas dan efisiensi proses penyampaian serta pemantauan informasi seputar RT kepada masyarakat secara cepat.

\section{HASIL DAN PEMBAHASAN}

Berdasarkan hasil analisis dari uji pretest dan posttest yang dilakukan terhadap 15 orang warga didapatkan hasil nilai sig (2-tailed) $=0,018$ dengan taraf signifikansi $0,001 \quad(\mathrm{p}<0,05)$ skor rerata pretest 62,18 menjadi skor rerata pos test 125,45 . Melihat perubahan angka antara pretest dan post test yang dilakukan menunjukan adanya perubahan yang signifikan pada tingkat pemahaman dan penggunaan aplikasi RT online hal ini membuktikan bahwa metode pelatihan atau pendampingan sangat efektif dilakukan untuk meningkatkan tingkat pemahaman dan keterampilan seseorang terhadap sesuatu hal dan hal ini selaras dengan penelitian (Mangkuprawira, 2004) pelatihan merupakan sebuah proses mengajarkan pengetahuan dan keahlian tertentu serta sikap agar semakin baik sesuai dengan standar.

Hasil dari kegiatan yang dilakukan berupa peningkatan keterampilan dan tingkat pemahaman warga terhadap penggunaan aplikasi RT online yang dapat digunakan oleh warga untuk mengetahui informasi seputar RT seperti grafik warga, grafik usia sekolah, kondisi kas RT, jadwal Ronda, mencari alamat Rumah warga dan pengurusan surat pengantar secara online. Proses pelatihan dan pendampingan.

Adapun tampilan dari aplikasi RT online adalah sebagai berikut : 


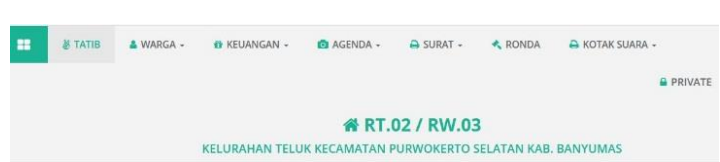

Gambar 1. Tampilan Aplikasi RT Online untuk warga

Dimana masing-masing fitur memuat informasi tentang warga, keuangan RT, Surat Pengantar Online, jadwal Ronda dan kotak suara untuk saran kepada pengurus RT.

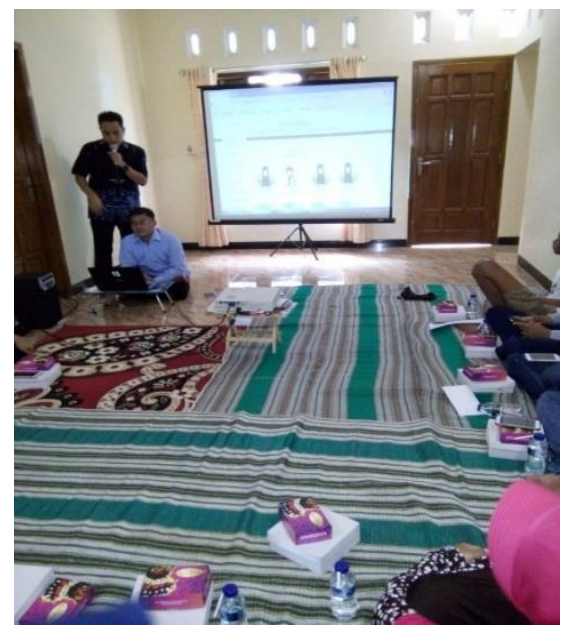

Gambar 2. Proses Pelatihan dan Pendampingan aplikasi RT online RT 02 Kelurahan Teluk Purwokerto Selatan

Proses pendampingan dilakukan dengan melibatkan warga secara langsung sebanyak 15 warga telah membawa dan mempersiapkan smartphone mereka untuk secara bersamaan mempraktikan langsung menggunakan aplikasi RT online yang dipandu oleh trainer dari pengurus RT melalui projektor sehingga warga dapat dengan mudah mengikuti apa yang disampaikan.

Warga terlihat aktif dan antusias dalam pelatihan tersebut dengan sering bertanya terkait aplikasi RukunTetangga online dan warga merasa senang dengan adanya inovasi baru yaitu RT online yang mungkin tidak ada di RT tempat lain, dan tentu hal ini membuat warga dapat saling kenal satu dengan lain dengan adanya aplikasi RT online ini, warga lebih mudah mendapatkan informasi terkait lingkungannya yang disebut dengan Rukun Tetangga.

Tanggapan warga adanya pelatihan warga cukup puas dan terbantu yang selama ini proses administrasi warga dilakukan secara manual sekarang beralih ke era teknologi internet yang menjadikan warga lebih mudah mendapatkan layanan informasi seputar RT.

Melalui kegiatan ini pengetahuan masyarakat tentang teknologi internet dan bagaimana memanfaatkan teknologi internet untuk mendapatkan informasi seputar kegiatan RT dapat meningkat dari yang sebelumnya hal ini dapat diketahui dari hasil angket yang diberikan kepada peserta pada akhir proses pendampingan.

\section{SIMPULAN}

Kegiatan pendampingan atau pelatihan penggunaan aplikasi RT online yang dilaksanakan mampu meningkatkan pemahaman dan keterampilan penggunaan aplikasi RT online untuk warga dalam mengurus administrasi ditingkat RT dan kemudahan warga untuk mendapatkan informasi secara up todate terkait RT diharapkan warga untuk selalu menggunakan aplikasi RT online untuk mengurus masalah terkait dengan RT.

\section{DAFTAR PUSTAKA}

Al-Fedaghi, S., (2011). Developing web applications. International Journal of

Bariyyah \& Permatasari. D., (2017), Pelatihan Pemanfaatan Media Online dalam Layanan Bimbingan Konseling bagi Konselor Sekolah Menengah Pertama diKabupaten Pamekasan Madura. Jurnal Pengabdian kepada Masyarakat IKIP PGRI Jember, 1(1), 63-69.

APJII. (2019). Penetrasi \& Perilaku Pengguna Internet Indonesia. From https://www.apjii.or.id/survei2019, 25 April 2019 
Sugiono, (2012). Memahami Penelitian Kualitatif dan $R$ \& $D$. Bandung: Alfabeta.

Mangkuprawira, S., (2004) Manajemen Sumber Daya Manusia Strategi, Jakarta Selatan : Ghalia Indonesia. 